\title{
Enhancing Student Engagement by Building upon the 'Tectonic Plates' of Legal Education
}

\author{
Simon Brooman
}

Published online: 28 August 2011

(C) Springer Science+Business Media B.V. 2011

Not many in the United Kingdom do it. But Australian's seem to do it a lot. Some UK law schools may have one or two doing it but the other law academics most often ignore them and turn a blind eye pretending it's not happening. It is suggested by some that we should all be doing it a lot more!

I am, of course, referring to the engagement of law teachers in pedagogical research.

It has long been suggested that law teachers are, for some reason, reluctant to publish in the area of legal education or even 'ignorant about theories of learning' (Fitzgerald 2008). As a group we tend to almost exhaustively engage in subjectrelated research-despite the excellent work and encouragement in the UK of, for example, the United Kingdom Centre for Legal Education and The Law Teacher. My experience in higher education is that most law academics have never considered writing in this area-even though many of them do some excellent work on creating stimulating learning environments for students which might be of interest to other law teachers. Having discussed this with some of my colleagues none of us can pinpoint exactly why this should be the case. In spite of small pockets of resistance doing some excellent work, there appears to be a similar story across UK law schools. Some have highlighted the comparatively ancient roots of legal education. 'Dear chap, why would we want to change when we've been doing this for 400 years?' remarked someone at a recent conference I attended, slightly tongue in cheek. Discussion of the accuracy of his time-scale aside, the discipline of law does seem to move very slowly around its core. As students, then tutors, of law we become passengers on the tectonic plates of legal education-the need to develop expertise in searching for rules and precedent, the dexterity of thought to apply these to new circumstances and the ability to present a, logical, reasoned argument to convince others that your interpretation is most likely to be correct.

S. Brooman $(\bowtie)$

School of Law, Liverpool John Moores University, Liverpool L3 5UZ, UK

e-mail: s.d.brooman@ljmu.ac.uk 
It could be said that these are the most valuable transferable skills that a law student develops. They have moved over time, but only according to a 'geological' timescale and they form the basis of our law degrees.

However, there is a persuasive argument to be made that law teachers should engage in more pedagogical activity to examine the educational structures we build upon the bedrock so as to pass on our core values and skills. It would help to test and disseminate the effectiveness of legal education. Are the structures and methods of delivery robust? Do they engage students? How do we know? At the very least, it seems odd that a discipline rooted in 'proof' and 'evidence' should be reluctant to produce sufficient proof in relation to the design of suitable learning environments. In my experience, such research can be beneficial to students, academic staff and the university alike through, for example, improvements in retention and student engagement (Brooman and Darwent 2011). There are many outside influences that are shaping legal education and it is surely right that we should examine what we do (Zepke and Leach 2010). There are many areas in legal education that are overdue for new or continued research and evaluation such as:

- teaching strategies to deal with increasing student numbers;

- discovering how advances in other areas of education such as psychology (e.g. emotion and self-efficacy) relate to the teaching of law;

- the place of reflection in undergraduate law teaching;

- identifying the value of the core skills developed by law students;

- the design and value of innovative learning environments such as simulated workplace exercises;

- ways to improve the engagement and performance of first and second year law students;

- the use of technology in learning and teaching delivery;

- innovative methods of delivering core law subjects and;

- use of student mentoring and peer-group learning.

The five articles published in this Special Edition present the research of academic law teachers who all have certain aspirations in common-a willingness to take a risk, to improve the student experience and to evaluate what they have done. If one theme permeates throughout it is student engagement. This area has been the subject of much research in higher education (Trowler and Trowler 2010). It informs learning and teaching development and, in turn, ensures quality enhancement appropriate to different disciplines.

As if to echo the dangers of our preoccupation with the law as a 'black-letter' subject, Dawn Watkins' opening article in this edition examines whether studentlearning in law might benefit from not viewing law as an 'absolute truth'presenting an alternative to viewing law as a set of precedents to be learned. Watkins argues that there is another way through the use of 'narrative' in legal education. The article suggests that the undergraduate law degree could benefit from the use of 'story-telling' narrative which might enhance its value as a broad liberal education. It enables students to appreciate their potential future place in shaping the real lives of real people. This article highlights the value of a degree in law as education when some might consider it to be merely training. Watkins adds to 
the growing body of literature questioning whether it is right for legal education to completely subrogate the lives of real people to legal principles. Finally, she discusses whether this different approach might enrich students' understanding and experience of 'learning the law'.

There is evidence of a move away from the traditional lecture/seminar approach to undergraduate legal education. Most of us will have experience in trying to motivate and engender genuine student interest in the subject rather than studying law for the more mechanistic aim of mark acquisition. In their article on the delivery of a module about the 'slippery concept' of dissent, Sarah Mercer, Chris Rogers and Clare Sandford-Couch present an evaluation of an ambitious attempt to create a more invigorating learning environment. Could they bring out deeper learning by radically changing the format of a module using innovative approaches, methods and sources? What did the students think of it and did it work? The authors consider the extent to which a challenging module design fosters the power of student imagination to develop more creative and critical thinking.

An area which has attracted significant research interest in recent times is the retention and engagement of first-year students (Yorke 1999). In the first of two articles on the first-year law student experience Sandra Clarke's discusses the use of an on-line discussion forum which aims to tackle both attrition rates and student engagement. Clarke's inquiry discusses the effectiveness of drawing on the experience of another discipline, psychology, in designing a new on-line discussion forum intervention to improve acclimatisation and retention of first-year law students as part of a legal methods module. The environment and influences under which this development takes place will be familiar to many of us dealing with the early transition of first-years. These include, for example, the havoc caused by unreliable registration lists and the dangers of assuming students already know everything there is to know about technology. But this article shows what may be achieved through 'electronic innovation' and reviewing the effectiveness of what we do. Part of the interest in this article lies in the fact that, as the author suggests, it is a 'cautionary tale'.

In the second article related to the first-year experience Cherry James focuses more specifically on the early induction of first-year law students. As the number of students entering university has increased so providers of law degrees, along with other disciplines, have had to re-think how students are inducted into university life. Most law schools appear to have created and re-invented induction strategies in isolation. It is a good example of where more available information and research as to what others were doing might have helped. James' article provides analysis of how familiar problems were dealt with and evaluated in her department from which we can all learn. She also usefully discusses whether induction initiatives might draw on local circumstances so as to add meaning to the process.

If undergraduate legal education is often ignored as a subject for research then post-graduate legal education fairs even worse! Tom Serby's article is a welcome piece of pedagogical research to remedy this lacuna and a second in this special edition examining the virtues and problems associated with an on-line intervention-this time in relation to Legal Practice Course students. Serby discusses whether there is value to be attained from innovative module design on the LPC 
which encompasses significant student peer-interaction. Are the costs in time and effort outweighed by the rewards? Serby's article speaks of the commitment necessary which has the potential to create a better learning environment. At a time when it is suggested that classroom contact is the panacea to student learning can some of our most creative work actually still take place outside the classroom?

The practical value of studies such as those included in this Special Edition of the Liverpool Law Review ought to be self-evident to legal educators. Such evaluative and critical research is vital to the creation of vibrant learning environments in legal education. In addition, there may be further value to be gained in relation to the wider discussions about legal education as the UK higher education law-teaching profession has been on the defensive in recent times. Encased in a certainty that we are doing what has always been done, we believe we have the weight of historical practice as our proof of our success. It comes as a surprise when people begin to ask whether we are still relevant or not. Are we providing broad liberal education or are we engaged in the development and creation of legal professionals? What are we for? Why are universities teaching law at all? Are there too many law students? Would the professions be better taking legal education in-house?

More engagement with pedagogical research would provide an opportunity to support each other by testing and disseminating what we do. By disseminating evidence of success and failures, this will aid improvements in the way in which we deliver legal education. We will be able to identify the core attributes of law graduates more clearly and articulate the broader value of legal education to prospective students and employers - those skills and attributes of good law graduates that most of us recognise by instinct.

For whatever purposes and value we identify, the challenge is to provide evidence that we're doing it right.

Acknowledgments As well as thanking the contributors and reviewers for their respective efforts I would like to thank Dr. Lorie Charlesworth, Editor in Chief of the Liverpool Law Review, for her support and advice during the editing of this edition. I would also like to thank Sue Darwent, Pedagogic Researcher in Law at LJMU for her invaluable input, appreciation and general knowledge of the subject and I wish her well for the future.

\section{References}

Brooman, S., and S. Darwent. 2011. "Yes, as the article suggests, I have considered dropping out": Selfawareness literature and the first year student. Studies in Higher Education 36(4), (in press).

Fitzgerald, M. 2008. Rite of passage: The impact of teaching methods on first year law students. The Law Teacher 42(1): 60-84.

Trowler, V., and P. Trowler. 2010. Student engagement evidence summary. York: The Higher Education Academy.

Yorke, M. 1999. Leaving early: Undergraduate non-completion in higher education. London: Routledge Farmer.

Zepke, N., and L. Leach. 2010. Improving student engagement: Ten proposals for action. Active Learning in Higher Education 11(3): 167-177. 